\title{
"US" AND “THEM" IN THINGS FALL APART BY CHINUA ACHEBE: A CRITICAL FUNCTIONAL APPROACH OF OTHERING
}

Lusia Kristiasih Dwi Purnomosasi $\varangle$; Department of English Teaching, Faculty of Teacher Training and Education, Universitas PGRI Madiun, Indonesia.

Vastukencana Sih Gita Garudatama ; Department/Program of Political Science , Faculty of Social and Political Science, Universitas Airlangga, Indonesia.

Sigit Ricahyono; Master's Program of Indonesian Language and Literature Education,

Postgraduate Program, Universitas PGRI Madiun, Indonesia.

\begin{abstract}
Us" and "them" or othering often brings about world's most feared phenomenon, xenophobia. This qualitative study purposes to disclose attitudinal strategies used in Chinua Achebe's "things Fall Apart". An excerpt from it was analysed through the "APPRAISAL", especially the "ATTITUDE", and 'PERIODICITY" theories. R esults reveal that "us" is framed with $4(+)$ values and only 2 in (-) while "them" is constructed through only $1(+)$ value and 3 $(-)$. The vast majority of the attitudinal strategies used is "Jdg.", occurring 7 times making up $70 \%$. The other which emerges is "Apr." which appears only 3 times and contributes $30 \%$. As commonly held, "us" is narrated in more favors and fewer negatives and "them" in the opposite way to achieve planned hidden goals of persuasion.
\end{abstract}

Keywords: "Us" and "them", Othering, Functional Approach, Periodicity, Appraisal, Attitude, Things Fall Apart.

$\bowtie$ lusiakdp@unipma.ac.id

Citation: Purnomosasi, L. K. D., Garudatama, V. S. H., \& Ricahyono, S. (2021). "us" and "them" in things fall apart by chinua achebe: A criticalfunctional approach of othering. Social Sciences, Humanities and Education Journal (SHE Journal), 2(1), 47 - 56. DOI: 10.25273/she.v2i1.8610

\section{(c) $)$ EY-NC-SA}

Published by Universitas PGRI Madiun. This work is licensed under the Creative Commons AttributionNonCommercial-ShareAlike 4.0 International License. 


\section{INTRODUCTION}

"Us" and "them" or "othering" is getting its momentum nowadays. For one thing, this may lead to prejudice, and, worst, xenophobia, "fear and hatred of strangers or foreigners or of anything that is strange or foreign" (https://www.merriamwebster.com/dictionary/xenophobia). This kind of phobia can hammer the UN's 17 Sustainable Development Goals (SDGs) and bring damages to poverty eradication, justice, and national harmony. It is no doubt, therefore, that only within 0.55 seconds in a google search it shows $14,200,000$ results. "Us" versus "them" is an alarming world phenomenon.

"Us" and "them" is commonly practiced in narratives through manipulating language, the main means of communication which embodies cultural reality through verbal and nonverbal symbols (Kramsch, 2001: 3; 2011). Through exchanges of such symbols, perceptions of whether good or bad, of right or wrong are constructed and reconstructed or negotiated. It is, therefore, always political and ideological in nature. Literature, through which the message is communicated, is, likewise, always a contested arena where ideologies hidden inside are either vested or resisted, including otherization of people as whether belong to "us" or "them". This article is purposed to analyze the attitudinal strategies used to construct "us" and "them" in Chinua Achebe's best known novel Things Fall Apart.

Dated literatures on the novel Things Fall Apart show that there are only a handful studies. Wafula \& Wanjala (2017) using narrative technique with analytical perspectives proposed by Gary Morson, close reading and content analysis of the primary text, came to conclusion that Achebe used techniques which are predicted, juxtaposed comparatively, and contrastive positions as the narrative devices. These enabled him to communicate effectively in the novel. Cairns (1985) examined the style, structure and the status of language in Chinua Achebe's Things Fall Apart and Arrow of God. Symbolic structure in Things Fall Apart caught the attention of Weinstock \& Ramadan (1968). Eisenberg (2016) conducted a critical examination of the epistemological and pedagogical risks and rewards of teaching Chinua Achebe's Things Fall Apart in American secondary schools. It was found that American students receive little about Africa in school and Things Fall Apart had been the American English Language Arts classroom since at least the 1970s, and became the only African literature taught in public schools in America. Gosling (2017) concerned on historical examples to draw on Chinua Achebe's novel Things Fall Apart, and investigated the transformation, dynamics, conflicts, traditional culture that were affected by colonialism. Themes of identity, authority, masculinity, justice, change, virtue and otherness emerge as among those to learn.

As can be seen, there is no study on Things Fall Apart focusing on othering strategies. The current study, as a consequence, seizes this gap by looking into attitudinal strategies employed in the novel to contruct "us" and "them".

\section{Literature Review on Otherization "Us" and "Them"}

Othering people by dividing them into 2 opposing "us" versus "them" is but about valuing or labeling with either good $(+)$ or bad $(-)$ features. This often leads to prejudice which often ends in illtreatment, disharmony, and civil clashes. This topic, accordingly, is worth to be 
investigated through an unbiased lens. As far the literatures are concerned, there has been a good deal of studies involving researchers from different academic backgrounds, employing different approaches, methods and perspectives.

Fangen (2020) examined antiIslamic sentiments in 2 Facebook groups. Stereotypes were used, that "them" muslim men were dangerous and muslim women were victims by way of explicit sexist language. Group xenophobia was built through humors, emotions and jargons.

Baron \& Dunham conducted a research on whether group membership affects the acquisition of richer information about social groups. The results reveal that children were more likely to generalize negative behaviors to "them" / outgroup members and positive behaviors to "us" / ingroup members.

Jamil (2020) illustrated the politics of fear during Malaysia's 13th general election by analyzing editorials in four paid-for Malay-language newspapers from the lens of Discourse-historical Approach's (DHA). The results reveal that everything was constructed as a threat or fear, i.e. fear of change, of loss of privilege, of the future, of other races to "us".

Valverde \& Perez-Martin (2020) applied theories of othering and Derrida's hauntology to investigate representation of border crossing and other migration experiences in the shadow play Ghosts of the River, written by Octavio Solís performed by the ShadowLight Company. It was uncovered that in the use of the ghost trope in fictional texts, the ghost embodies "us" as the oppressed reappearing as a haunting figure that questions the established order.
Ezzati (2021) conducted a study concerning on whether Muslim immigrants can adapt to Western values after the 2011 terror attacks in Norway. It was revealed that an enlarged 'we' that supersedes ethnic and religious divisions was used to construct "us". It, therefore, challenges widely accepted views to values as core traits that divide cultural or political groups in society.

Barr, McKay \& Doroshow (2021) analyzed discriminatory treatment to Asian Americans, especially Chinese, because of the association of the COVID19 which originated from Wuhan, China. It was uncovered that "them" / Chinese were treated negatively, for example, when Public health officials were quick to quarantine Chinatown while leaving the rest of the city largely unrestricted. Others include insisting on autopsies of suspicious deaths, requiring vaccinations, and forced relocations, were selectively implemented among Asian American communities.

Abascal (2015) investigated blackwhite relations in the United States regarding Hispanic population growth and found that blacks and whites showed opposite reactions. Whites in the baseline condition contribute comparable amounts to black and white recipients in a dictator game and whites who first read about Hispanic growth contribute more to white recipients than to black ones. In contrast, blacks in the baseline condition contribute more to black recipients than to white ones and blacks who first read about Hispanic growth contribute comparable amounts to black and white recipients.

Kharshiing (2020) examined how the tribal Khasis in Meghalaya, India otherized the non-tribal people drawn from in media texts drawn from Englishmedium newspapers, magazines and a blog through Critical Discourse Analysis. Among others, ways of othering include 
identity threat, race-based differentiation and loss of citizenship. Hellman \& Lerkkanen (2019) studied a 2-hour-long live televised debate by the Finnish public service broadcasting company YLE about asylum seekers in 2015 in which a classic polarization construct between 'us' (Finnish people) and 'them' (refugees) emerged. "Them" were put to the test to demonstrate their compliance with right sorts of otherhood; they were asked to eat Finnish food and show their skills in the Finnish language.

Cikara, Botvinick \& Fiske (2011) investigated Avid fans of the Red Sox and Yankees teams to shed light on whether valuation-related neural responses to rival groups' failures correlate with likelihood of harming individuals associated with those rivals and revealed that Subjectively negative outcomes (failure of the favored team or success of the rival team) activated anterior cingulate cortex and insula, whereas positive outcomes (success of the favored team or failure of the rival team, even against a third team) activated.

Lehr, Ferreira \& Banaji (2019) studied the intergroup emotions of fans of the Boston Red Sox and New York Yankees and their results indicate that pleasure from a powerful rival's losses can outstrip that from gains of one's own group;fans of the rival teams frequently valued outgroup losses more than ingroup gains, and this effect was particularly strong when one's own team was behind in the rivalry.

Marinthe, Falomir-Pichastor, Testé \& Kamiejski (2020) studied ingroup favoritism where French participants were asked to imagine the ingroup/competition outgroup flag being burnt by ingroup/competition outgroup perpetrators. Results indicate that imagining the ingroup flag being burnt increased proingroup bias through increase in either ingroup favoritism, as shown in Study 1, or outgroup derogation.

\section{ATTITUDE and APPRAISAL Theory, and Periodicity Theory}

"Attitude" is a sub-category in "Appraisal" theory which is about evaluation. Attitude is basically about valuing or giving labels which is used to negotiate meanings with readers (Martin and Rose, 2007: 18-38). The object of the valuing or the labeling can be persons or people, things or objects, or feelings or emotions. The first is termed "judgment" (Jdg.), the second is "Appreciation" (Apr.) and the last is "Affect" (Aff.). The value attached to or embedded in one of the three can be either positive $(+)$ or negative (-) with the degree of either high $(\mathrm{H})$, median $(\mathrm{M})$, or low (L). The degrees, (H) for example, realized implicitly or explicitly through, for instance, the presence of such comparative and superlatives as better, best, or through taboos or figurative language.

Periodicity is, by and large, about information flow, about how meaning is organized, or packed (Martin and Rose, 2007: 187). In "little wave" level, clauses are divided into "theme" which is further subdivided into "marked" (M) and "unmarked" (UnM) and "New" (N). "Theme" constitute the starting point of a clause or what the clause is going to be. (UnM) is where the "theme" is the "subject" of the clause. Otherwise, it is called (M). The (N) is what is believed will be new for listener or reader. In written text this is realized as the part in the final position of a clause.

\section{Summary of Things Fall Apart}

The main character of this novel is Okonkwo. He is a strong and great man whose father was lazy and of no titles. He is among Ibo tribe members who lives in his home of Umuofia. It is a group of nine 
villages somewhere in Nigeria. He does his best not to be like his father. During his youth, he has been building his reputation to be a strong man. He, for example, defeated a reputable wrestler, which leads him to ultimate fame among the villagers. Being weak and emotional is by no means an option for his life. All this makes him powerful, wealthy, and best known across the village and finally becomes the chief of the village. This position is what he has ever fought for.

Among the consequences of such fame is that he appointed by elders to be the guardian of an imprisoned boy named Ikemefuna. Ikemefuna is taken prisoner in consequence of a peace settlement between two villages. Ikemefuna has to stay with him until the elders inform what to do. It has been about three year lap that he has been with Ikemefuna. The length of stay creates a strong bond of kinship between the two. It is no doubt that Ikemefuna considers him his father. It is time that the elders decide that Ikemefuna has to be killed. The elders prevent him from doing the killing by him. However, in order that he does not seem weak and emotional, he helps to kill Ikemefuna.

Days following the death of Ikemefuna are marked with everything is wrong for him. It begins as he by accidence kills a man at a funeral ceremony. Soon afterwards, he and his family members are exiled as long as seven years. It is during his absence in the village that white men begin to come to his village, Umuofia. The whites bring with them their religion as well. They come in peace which makes more and more villagers converted into the new religion. As the number of the converted grows, they establish a new government, replacing the old one.

Okonkwo returns to his village after his exile to find it a changed place because of the presence of white men. He and other tribal leaders try to reclaim their hold on their native land by destroying a local Christian church that has insulted their gods and religion. In return, the leader of the white government takes them prisoner and holds them for ransom for a short while, further humiliating and insulting the native leaders. The people of Umuofia finally gather for what could be a great uprising, and when some messengers of the white government try to stop their meeting, Okonkwo kills one of them. He realizes with despair that the people of Umuofia are not going to fight to protect themselves because they let the other messengers escape and so all are lost for the Ibo tribe. When the local leader of the white government comes to Okonkwo's house to take him to court, he finds that Okonkwo has hanged himself which ruins his great reputation.

\section{METHOD}

This study is qualitative in nature and adopt the "Five Phased Cycle" by Yin (2016: 186) which include: 1) compiling, 2) disassembling, 3) reassembling, 4) interpreting, and 5) concluding. Theories applied are the "Periodicity" and "APPRAISAL" specifically the "ATTITUDE". As the study focuses on "ideation" i.e. how participant's activities are described and labeled, the two are relevant. The "Periodicity" will shed light on which one is "described", which coincides with the "theme", and which is "describing", which is served in the "new". "APPRAISAL"'s "ATTITUDE" will disclose the values and the degree of the values invested in the chosen words or phrases used to describe a given person or thing. To validate the values and the degrees, Cambridge Dictionary, MeriamWebster Dictionary and MacMillan Dictionary are consulted. The data are excerpted from Chinua Achebe's Things Fall Apart selected in accordance with the plot structure to make sure wholeunity of the text. In short, all type of data are qulitative in terms of clauses and chunks which include words and or phrases. Frequency of occurrences is presented as supplementary to the verbal data. 


\section{RESULTS}

Results on the bases of "periodicity" and "ATTITUDE" analyses are presented in the following tables in that order.

As can be seen from table 2, the vast majority of the attitudinal strategies used is "Jdg.", occurring 7 times making up $70 \%$. The other which emerges is "Apr." which appears only 3 times and contributes 30\%. "Aff." does not present at all. Regarding the otherization, "us" is framed with $4(+)$ values and only 2 in (). In contrast, "them" is constructed through only $1(+)$ value and 3 for (-).

Tabel 1. Periodicity analysis "theme-new"

\begin{tabular}{|c|c|c|}
\hline No. & Theme & New \\
\hline $1 \mathrm{a}$ & $\begin{array}{l}\text { Among the Igbo (M) the art of } \\
\text { conversation (UnM) }\end{array}$ & is regarded very highly, \\
\hline $1 \mathrm{~b}$ & and proverbs (UnM) & are the palm-oil with which words are eaten. \\
\hline 2 & Yam, the king of crops (UnM) & was a man's crop. \\
\hline 3 & The white man (UnM) & is very clever. \\
\hline 4 & He (UnM) & came quietly and peaceably with his religion. \\
\hline 5 & We (UnM) & were amused(a) at his foolishness (b) \\
\hline 6 & And (We) (UnM) & allowed him to stay. \\
\hline $7 a$ & Now (M) he (UnM) & has won our brothers, \\
\hline $7 \mathrm{~b}$ & and our clan (UnM) & can no longer act like one. \\
\hline $8 a$ & He (UnM) & has put a knife on the things that held us together \\
\hline $8 b$ & and we (UnM) & have fallen apart. \\
\hline
\end{tabular}

Tabel 2. Attitudinal strategy analysis

\begin{tabular}{|c|c|c|c|c|}
\hline \multirow[t]{2}{*}{ Data } & \multicolumn{2}{|c|}{ “us" } & \multicolumn{2}{|c|}{ "them" } \\
\hline & Positive $(+)$ & $\begin{array}{c}\text { Negative (- } \\
\text { ) }\end{array}$ & $\begin{array}{c}\text { Positive } \\
(+)\end{array}$ & Negative (-) \\
\hline $\begin{array}{l}\text { Among the Igbo the art of } \\
\text { conversation is regarded(1) } \\
\text { very highly, and proverbs are } \\
\text { the palm-oil with which words } \\
\text { are eaten(2). }\end{array}$ & $\begin{array}{l}\text { 1) Apr. H } \\
\text { 2) Apr. H }\end{array}$ & & & \\
\hline $\begin{array}{l}\text { Yam, the king }(3) \text { of crops was a } \\
\text { man's crop. }\end{array}$ & 3) Jdg. H & & & \\
\hline The white man is very clever(4). & & & & 4) Jdg. H \\
\hline $\begin{array}{l}\text { We were amused at his } \\
\text { foolishness }(5) \ldots . .\end{array}$ & & & & 5) Jdg. M \\
\hline $\begin{array}{l}\text { Now he has won(6) our } \\
\text { brothers, and our clan can no } \\
\text { longer act( } 7 \text { ) like one. }\end{array}$ & & 7) Jdg. H & 6) Jdg. M & \\
\hline $\begin{array}{l}\text { He has put a knife }(8) \text { on the } \\
\text { things that held us together( }(9) \\
\text { and we have fallen apart }(10)\end{array}$ & 9) Apr. H & 10) Jdg. H & & 8) Jdg. H \\
\hline Distribution of Value Grades & $4(40 \%) \mathrm{H}$ & $2(20 \%) \mathrm{H}$ & $1(10 \%) \mathrm{M}$ & $\begin{array}{r}3(30 \%) \\
\left\{\begin{array}{c}2(20 \%) H ; \\
1(10 \% M\end{array}\right\}\end{array}$ \\
\hline Distribution of Attitude & $\begin{array}{l}\text { Apr. } \\
3(30 \%) \\
\text { Jdg. } 1(10 \%)\end{array}$ & $\begin{array}{r}\text { Jdg. } \\
2(20 \%)\end{array}$ & $\begin{array}{r}\text { Jdg. } \\
1(10 \%)\end{array}$ & Jdg. $3(30 \%)$ \\
\hline & & $6(60 \%)$ & & $4(40 \%)$ \\
\hline Total Attitude & Jdg. 7(70\%) & $\begin{array}{l}3(30 \%) \text { Apr. } \\
3(30 \%) \mathrm{Jdg} . \\
\text { Apr. }(30 \%)\end{array}$ & Aff. 0 & $4(40 \%) \mathrm{Jdg}$ \\
\hline
\end{tabular}


Attitudinal Strategies to Contruct "Us"

Data 1) "Among the Igbo the art of conversation is regarded(1) very highly, and proverbs are the palm-oil with which words are eaten(2)".

In 1(1), 2 themes are spotted, i.e. "Among the Igbo" which is (M) and "the art of conversation" which is the subject and therefore becomes (UnM). In the clause, the UnM serves as the participant whose activity description and label are available in the $(\mathrm{N})$. The kind of "attitude" adopted here is, therefore, (Apr.). The chosen "regarded" contains positive $(+)$ value as shown in Cambridge Dictionary "/ri'ga:d/ respect or admiration for someone or something" (https://dictionary.cambridge.org) and the Meriam-Webster Dictionary " $\backslash \mathrm{ri}$ 'gärd \a feeling of respect and affection; esteem" (https://www.merriamwebster.com/dictionary/regarded). The $(+)$ value is in $(\mathrm{H})$ degree as realized explicitly by the presence of the choice of the word "very". In other words, the "N" carries "Appr" of a H degree (+) value to the UnM used to frame "us".

In 1(2), the UnM "proverbs" is described in the " $\mathrm{N}$ " as "the palm-oil with which words are eaten" which is also an "Apr." realized implicitly through a metaphor containing a (+) value and inherently $\mathrm{H}$ in degree on account of the metaphor. It follows, therefore, here in 1(2), "Apr." (+), (H) is deployed to frame "us". Altogether, 1(1) and (2) highlight that Igbo people hold in their high esteem their culture of "rhetoric", characterizing the people of "verbal culture".

Data 2) "Yam, the king(3) of crops was a man's crop".

In data 2 which is a single clause the UnM "the king of crops" is described in the "N" as "a man's crop". The attitude adopted is (Jdg.). This because the description of "a man's crop" refers indirectly to Okonkwo. The (Jdg.) is realized implicitly through a metaphor which contains a $(+)$ and $(\mathrm{H})$ degree. In the UnM as well, another (Jdg.) is used through the insertion of the word "king". With reference to Cambridge Dictionary in which it is stated "/kı/ the most important, best, or most respected member of a group of animals, things, or people"

(https://dictionary.cambridge.org/dicti onary/english/king) and MeriamWebster Dictionary where it described " $\backslash$ 'kin \ a paramount chief" (https://www.merriam-

webster.com/dictionary/king), it is apparent that the value invested is $(+)$ one. The degree of the value is $(\mathrm{H})$ as indicated by "paramount" and superlative degrees "most important, best, most respected".

The quote in data 2 underlies that masculinity is adhered in Igbo society and at the same time puts one's ability to support a family on priority for men. Okonkwo, accordingly, makes himself fit the masculine culture requirement. His consistent hardwork pays off and turns him into a successful Yam farmer. In short, "us" in data 2 is featured as being $(+)$ in $(\mathrm{H})$ degree by making use of (Jdg.).

\section{Attitudinal Strategies to Contruct "Them"}

Data 3) "The white man is very clever(4)".

In data 3 which a single clause, the UnM "The white man" is decribed in "N" as "clever". The kind of attitude employed is (Jdg.) which an embedded () value. In Cambridge Dictionary a description says "/'klev.ər/ showing intelligence, but not sincere, polite, or serious"

(https://dictionary.cambridge.org/dicti onary/english/clever) and the same is found in Meriam-Webster Dictionary " 
'kle-vər \marked by wit or ingenuity" (https://www.merriam-

webster.com/dictionary/clever). The preceding adverb "very" scales up the degree of the value into $(\mathrm{H})$. It is apparent here that "them" "The white man" is presented to contain a $(\mathrm{H})(-)$ value.

Data 4) "We were amused at his foolishness(5) ....".

In data 4, The UnM is given description in the " $\mathrm{N}$ " where it is found "his foolishness". The category of attitude used belongs to (Jdg.) as the possessive pronoun "his" refers to the white people. The value brought is (-) as depicted in MacMillan Dictionary "/'fuilis/ lacking good sense and judgment" (https://www.macmillandictionary.com /dictionary/british/foolish) as well as in Cambridge Dictionary "/'fur.lif/ unwise, stupid, or not showing good judgment" (https://dictionary.cambridge.org/dicti onary/english/foolish). Absence of superlatives or comparatives or figurative language indicates that the degree of the (-) value is median (M). "Them" here is portrayed with an (M) (-) value.

\section{DISCUSSION}

This study concerns with how attitudinal strategies are used for othering in terms of "us" versus "them" by applying "periodicity" and "Appraisal" theories in the systemic functional perspective. It is uncovered that "us" is described in more $(+)$ values than $(-)$ ones. The opposite is that "them", the whites, is featured with more (-) values than (+) ones. Most frequently used is Jdg. The other is Apr. No Aff. is found. This study, therefore, supports the vast majority of the previous ones where "us" tend to be portrayed favorably with more (+) values while "them" is the reverse, in more (-) (Fangen, 2020); (Baron \& Dunham, 2015); (Jamil, 2020); (Ezzati, 2021); (Barr et al., 2021); (Kharshiing, 2020); (Cikara et al., 2011) and
(Marinthe et al., 2020). This is against the work of valverde (2020) where "us" is featured as more in $(-)$ than $(+)$.

\section{CONCLUSION}

As what becomes the assumption of critical Discourse Analysis, no texts are neutral. All are contested where writers/authors/speakers invest their hidden motives through the words chosen and arranged, the wording, to put in other word. The wording, in its turn, can be used to frame who belongs to "us" and "them" circulated in narratives aimed at planned goals. In general, "us" is presented as "good" guys loaded with (+) values while "them" with (-) which may lead to biases and create prejudice and xenophobia. This highlights a call for critical literacy to be vested from childhood, in the classroom instructions, as well as wide societies. This literacy becomes paramount in nowadays "big data" era to be side by side with the digital humanities movement.

\section{DAFTAR PUSTAKA}

Abascal, M. (2015). Us and Them: BlackWhite Relations in the Wake of Hispanic Population Growth. American Sociological Review, 80(4), 789-813. https://doi.org/10.1177/000312 2415587313

Baron, A. S., \& Dunham, Y. (2015). Representing 'Us' and 'Them': Building Blocks of Intergroup Cognition. Journal of Cognition and Development, 16(5), 780-801. https://doi.org/10.1080/152483 72.2014.1000459

Barr, J., McKay, R. A., \& Doroshow, D. B. (2021). The Dangers of "Us Versus Them": Epidemics Then and Now. Journal of General Internal Medicine. https://doi.org/10.1007/s11606020-06368-y 
Cambridge Dictionary. (n.d.). "regarded". Retrieved February 01, 2021, from https://dictionary.cambridge.org/dict ionary/english/regard?q=regarded

Cambridge Dictionary. (n.d.). King. Retrieved February 01, 2021, from https://dictionary.cambridge.org/ dictionary/english/king

Cambridge Dictionary. (n.d.). Foolish. Retrieved February 01, 2021, from https://dictionary.cambridge.org/ dictionary/english/foolish

Cambridge Dictionary. (n.d.). Fall apart. Retrieved February 01, 2021, from https://dictionary.cambridge.org/ dictionary/english/fall-apart

Cairns, P. (1985). Style, structure and the status of language in Chinua Achebe's Things Fall Apart and Arrow of God. World Literature Written in English, 25(1), 1-9. https://doi.org/10.1080/174498 58508588917

Cikara, M., Botvinick, M. M., \& Fiske, S. T. (2011). Us Versus Them: Social Identity Shapes Neural Responses to Intergroup Competition and Harm. Psychological Science, 22(3), 306-313. https://doi.org/10.1177/095679 7610397667

Eisenberg, E. (2016). Things Fall Apart and the Pedagogy of Adichie's Single Story. Eastern African Literary and Cultural Studies, 2(34), 94-100. https://doi.org/10.1080/232774 08.2016 .1272188

Ezzati, R. T. (2021). Value-talk after terrorism: Articulating a united 'we' and a divided 'us'. Journal of Ethnic and Migration Studies, 47(1), 130-147. https://doi.org/10.1080/136918 3X.2020.1752637

Fangen, K. (2020). Gendered Images of us and Them in Anti-Islamic Facebook Groups. Politics, Religion \& Ideology, 21(4), 451-468. https://doi.org/10.1080/215676

89.2020.1851872

Gosling, J. (2017). Will we know what counts as good leadership if Things Fall Apart? Questions prompted by Chinua Achebe's novel. Leadership, 13(1), 35-47. https://doi.org/10.1177/174271 5016680675

Hellman, M., \& Lerkkanen, T. (2019). Construing oppositions, demarcating a we-ness: The dramaturgy of a live TV debate on the refugee crisis. European Journal of Cultural Studies, 22(1), 37-59. https://doi.org/10.1177/136754 9417719060

Jamil, S. N. M. (2020). 'Malaysia belongs to the Malays' (Malaysia ni Melayu Punya!): Categorising 'us' and 'them' in Malaysia's mainstream Malay-language newspapers. Critical Discourse Studies, O(0), 117. https://doi.org/10.1080/174059 04.2020 .1834419

Kharshiing, K. D. (2020). Identity and Otherisation in Northeast India: Representations in Media Texts. Psychology and Developing Societies, 32(1), 65-93. https://doi.org/10.1177/097133 3619900046

Lehr, S. A., Ferreira, M. L., \& Banaji, M. R. (2019). When outgroup negativity trumps ingroup positivity: Fans of the Boston Red Sox and New York Yankees place greater value on rival losses than own-team gains. Group Processes \& Intergroup Relations, 22(1), 26-42. https://doi.org/10.1177/136843 0217712834

MacMillan Dictionary. (n.d.). FALL APART (phrasal verb) definition and synonyms: Macmillan Dictionary. Retrieved February 01, 2021, from 
https://www.macmillandictionary.co $\mathrm{m} /$ dictionary/british/fall-apart

Mac Millan Dictionary. (n.d.). CLEVER (adjective) definition and synonyms: Macmillan Dictionary. Retrieved February 02, 2021, from https://www.macmillandictionar y.com/dictionary/british/clever

Marinthe, G., Falomir-Pichastor, J. M., Testé, B., \& Kamiejski, R. (2020). Flags on fire: Consequences of a national symbol's desecration for intergroup relations. Group Processes \& Intergroup Relations, 23(5), 744-760. https://doi.org/10.1177/136843 0219853352

Meriam-Webster Dictionary. (n.d.). Regarded. Retrieved February 01, 2021, from https://www.merriamwebster.com/dictionary/regarded Meriam-Webster Dictionary. (n.d.). King. Retrieved February 01, 2021, from https://www.merriamwebster.com/dictionary/king

Merriam-Webster. (n.d.). Clever. Retrieved February 02, 2021, from https://www.merriamwebster.com/dictionary/clever

Valverde, C. P., \& Perez-Martin, F. (2020). "There is no 'us and them": Engaging with Migration and Border Crossing Narratives through Shadow Puppetry in Ghosts of the River. Critical Arts, 34(4), 47-60. https://doi.org/10.1080/025600 46.2020.1721548

Wafula, R. M., \& Wanjala, C. L. (2017). Narrative Techniques in Chinua Achebe's Things Fall Apart. Journal of Social Sciences, 50(1-3), 62-69. https://doi.org/10.1080/097189 23.2017.1311740

Weinstock, D., \& Ramadan, C. (1968). Symbolic Structure in Things Fall Apart. Critique: Studies in Contemporary Fiction, 11(1), 3341. https://doi.org/10.1080/001116 19.1968.10689938

Yin, R. K. (2016). Qualitative research from start to finish (Second edition). The Guilford Press. 